Check for updates

Cite this: RSC Adv., 2018, 8, 23919

Received 30th April 2018

Accepted 15th June 2018

DOI: $10.1039 / \mathrm{c} 8 \mathrm{ra03696a}$

rsc.li/rsc-advances

\section{Synthesis of trifluoromethyl-containing isoindolinones from tertiary enamides via a cascade radical addition and cyclization process $\uparrow$}

\author{
Hui Yu, (D)* Mingdong Jiao, Xiaowei Fang and Pengfei Xuan
}

A radical trifluoromethylation reaction of tertiary enamides was investigated and trifluoromethyl-containing isoindolinones were prepared under mild conditions. Using $\mathrm{TMSCF}_{3}$ as a radical source, $\mathrm{PhI}(\mathrm{OAc})_{2}$ as an oxidant and $\mathrm{KHF}_{2}$ as an additive, tertiary enamides were converted to isoindolinones via a cascade addition and cyclization process in moderate to good yields.
In recent years, trifluoromethyl-containing azaheterocycles have attracted much attention for their potential application in the fields of pharmaceutical and agricultural chemistry. ${ }^{1}$ Thus, lots of efforts have been devoted to the synthesis of trifluoromethyl azaheterocycles, ${ }^{2}$ and among these developed methods, radical cascade addition and cyclization has emerged as a remarkable strategy due to its unique properties such as economy and high efficiency. Unsaturated amides are commonly used substrates for this type of transformation, which could be attacked by a $\mathrm{CF}_{3}$ radical followed by intramolecular $\mathrm{C}-\mathrm{O}, \mathrm{C}-\mathrm{N}$, or $\mathrm{C}-\mathrm{C}$ bond formation to give different kinds of trifluoromethyl azaheterocycles. Fu reported a metal-free trifluoromethylation of $\mathrm{N}$ allyamides with $\mathrm{CF}_{3} \mathrm{SO}_{2} \mathrm{Na}$ for the synthesis of trifluoromethylcontaining oxazolines via oxytrifluoromethylation. ${ }^{3}$ In the presence of copper salts, $N$-acyl-2-allylaniline could be converted to trifluoromethylated indolines in moderate to good yields via aminotrifluoromethylation process. ${ }^{4}$ With Togni's reagent, ${ }^{5} \mathrm{TMSCF}_{3},{ }^{6} \mathrm{CF}_{3} \mathrm{SO}_{2} \mathrm{Na},{ }^{7} \mathrm{CF}_{3} \mathrm{SO}_{2} \mathrm{Cl}^{8}$ and other reagents ${ }^{9}$ as the $\mathrm{CF}_{3}$ source, $\alpha, \beta$-unsaturated amides, tosyl amides, or imides underwent a tandem conversion to give trifluoromethylcontaining oxindoles or isoquinoline-1,3-diones by trifluoromethylation/arylation reaction. On the other hand, as a special type of unsaturated amide containing an active double bond, enamide also exhibited excellent reactivity in radical reactions. ${ }^{10}$ In fact, trifluoromethylation of enamides has already been investigated, and in most cases trifluoromethylated alkenes were obtained as the main products. ${ }^{11}$ To the best of our knowledge, the radical trifluoromethylation and cyclization of enamide still remains undeveloped.

School of Chemical Science and Engineering, Shanghai Key Lab of Chemical Assessment and Substainability, Tongji University, 1239 Siping Road, Shanghai, 200092, P. R. China. E-mail: yuhui@tongji.edu.cn; Fax: +86 21 65981097; Tel: +86 2165981097

$\dagger$ Electronic supplementary information (ESI) available: Detailed experimental procedures and characterization data for the products. See DOI: 10.1039/c8ra03696a
Isoindolinones are important $N$-heterocyclic compounds necessary in organic and pharmaceutical chemistry, and these compounds are used widely as anticoagulants and tranquilizers such as aristolactam, pagoclone, and zopiclone. ${ }^{12}$ To introduce $\mathrm{a} \mathrm{CF}_{3}$ group into isoindolinones, Wang and co-workers explored a convenient way to the synthesis of trifluoromethyl-containing isoindolinones by radical aminotrifluoromethylation (Scheme 1a) ${ }^{13}$ but this transformation only occurred for $\mathrm{N}$-methoxylbenzamides, and in case of $N$-alkylbenzamides trifluoromethylated alkenes were obtained as the major products. 1,1-disubstituted terminal alkenes were also not suitable substrates because of the competition between O-trapping and $\mathrm{N}$-trapping process. Thus, development a new method for the synthesis of trifluoromethyl-containing isoindolinones is still in demand. Here in, as a continuation of our efforts on the radical modification of amide derivatives,${ }^{14}$ we wish to present our work on the synthesis of trifluoromethyl-containing isoindolinones using enamides as the start materials by radical carbon trifluoromethylation (Scheme 1b).

Initially, $N$ - $n$-butyl- $N$-(2-propenyl) benzamide 1a was chosen as the model substrate to optimize the reaction conditions of this radical carbontrifluoromethylation process. As shown in Table 1, the reaction of $1 \mathrm{a}$ with $\mathrm{TMSCF}_{3}$ (4.0 equiv.) was firstly

a) Previous work: aminotrifluoromethylation

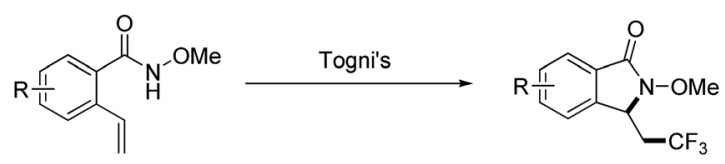

b) This work: carbontrifluoromethylation

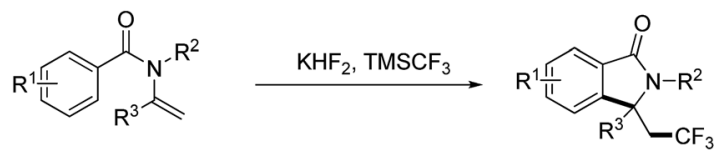

Scheme 1 Synthesis of trifluoromethyl-containing isoindolinones. 
examined in $\mathrm{CH}_{3} \mathrm{CN}$ with $\mathrm{PhI}(\mathrm{OAc})_{2}$ (4.0 equiv.) as the oxidant and $\mathrm{NaF}$ (1.0 equiv.) as the additive at $80{ }^{\circ} \mathrm{C}$ under $\mathrm{N}_{2}$ atmosphere. 12 hours later, all the start material disappeared monitored by TLC and the desired product 2a was isolated in $15 \%$ yield with $N$ - $n$-butyl benzamide isolated as the main byproduct (Table 1, entry 1). When KF and CsF was used instead of $\mathrm{NaF}$, the desired product $2 \mathrm{a}$ was obtained in $35 \%$ and $38 \%$ yield respectively (Table 1, entries 2 and 3). To our delight, when bifluoride was used as the additive, the yield of 2a could be improved significantly, and $\mathrm{KHF}_{2}$ gave better result than $\mathrm{NaHF}_{2}$ and $\mathrm{NH}_{5} \mathrm{~F}_{2}$ (Table 1, entries 4-6). Changing the solvent to $\mathrm{CH}_{3} \mathrm{CN}, \mathrm{CH}_{2} \mathrm{Cl}_{2}$ or toluene resulted in the formation of $2 \mathrm{a}$ in only $0-32 \%$ yields (Table 1, entries 7-9). Increasing the reaction temperature to $100^{\circ} \mathrm{C}$ or decreasing the reaction temperature to $60{ }^{\circ} \mathrm{C}$ and room temperature led to lower yield of $2 \mathrm{a}$ (Table 1 , entries 10-12). Another commercial oxidant $\mathrm{PhI}\left(\mathrm{OCOCF}_{3}\right)_{2}(4.0$ equiv.) was also tested but to give poor yield of $2 \mathrm{a}$ (Table 1 , entry 13). When the amount of $\mathrm{TMSCF}_{3}$ and $\mathrm{PhI}(\mathrm{OAc})_{2}$ was reduced to 3.0 equiv., only $62 \%$ yield of $2 \mathrm{a}$ could be isolated (Table 1 , entry 14). The amount of $\mathrm{KHF}_{2}$ was increased to 1.5 equiv. or decreased to 0.5 equiv. also caused lower yield of $2 \mathrm{a}$ (Table 1 , entry 15). Finally, 1.0 equiv. of NaOAc was added to the reaction but the yield of 2a was not improved (Table 1, entry 16). On the basis of these results, entry 5 represents the best conditions.

Under the optimized reaction conditions, the scope of substrates was investigated with results summarized in Table 2 . For substrates with methyl group substituted at different

Table 1 Screening conditions ${ }^{a}$
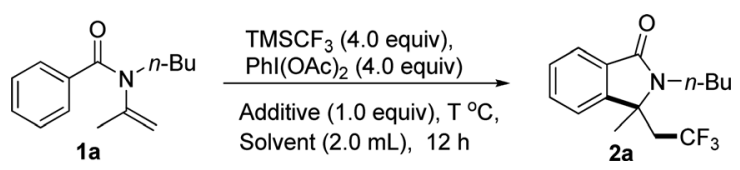

\begin{tabular}{lllll}
\hline Entry & $\begin{array}{l}\text { Additive } \\
(0.3 \text { equiv. })\end{array}$ & $\begin{array}{l}\text { Solvent } \\
(2 \mathrm{~mL})\end{array}$ & $\begin{array}{l}\text { Temp. } \\
\left({ }^{\circ} \mathrm{C}\right)\end{array}$ & $\begin{array}{l}\text { Yield of } \\
\mathbf{2 \mathbf { a } ^ { b }}(\%)\end{array}$ \\
\hline 1 & $\mathrm{NaF}$ & EtOAc & 80 & 15 \\
2 & $\mathrm{KF}$ & EtOAc & 80 & 38 \\
3 & $\mathrm{CsF}$ & EtOAc & 80 & 35 \\
4 & $\mathrm{NaHF}_{2}$ & EtOAc & 80 & 52 \\
5 & $\mathrm{KHF}_{2}$ & EtOAc & 80 & 75 \\
6 & $\mathrm{NH}_{5} \mathrm{~F}_{2}$ & EtOAc & 80 & 40 \\
7 & $\mathrm{KHF}_{2}$ & $\mathrm{CH}_{3} \mathrm{CN}$ & 80 & 21 \\
8 & $\mathrm{KHF}_{2}$ & $\mathrm{CH} \mathrm{Cl}_{2}$ & 80 & 32 \\
9 & $\mathrm{KHF}_{2}$ & Toluene & 80 & Trace \\
10 & $\mathrm{KHF}_{2}$ & EtOAc & 100 & 61 \\
11 & $\mathrm{KHF}_{2}$ & EtOAc & 60 & 43 \\
12 & $\mathrm{KHF}_{2}$ & EtOAc & r.t. & $\mathrm{NR}^{c}$ \\
13 & $\mathrm{KHF}_{2}$ & EtOAc & 80 & $37^{c}$ \\
14 & $\mathrm{KHF}_{2}$ & EtOAc & 80 & $62^{d}$ \\
15 & $\mathrm{KHF}_{2}$ & EtOAc & 80 & $58^{e}, 47^{f}$ \\
16 & $\mathrm{KHF}_{2}$ & EtOAc & 80 & $73^{g}$
\end{tabular}

${ }^{a}$ The reaction was carried out on $0.2 \mathrm{mmol}$ scale in a sealed tube under $\mathrm{N}_{2} \cdot{ }^{b}$ Isolated yield. ${ }^{c} \mathrm{PhI}\left(\mathrm{OCOCF}_{3}\right)_{2}$ (4.0 equiv.) was used as the oxidant. ${ }^{d}$ Reaction carried out with $\mathrm{PhI}(\mathrm{OAc})_{2}$ (3.0 equiv.) and $\mathrm{TMSCF}_{3}$ (3.0 equiv.). ${ }^{e}$ With 1.5 equiv. $\mathrm{KHF}_{2} .{ }^{f}$ With 0.5 equiv. $\mathrm{KHF}_{2} .{ }^{g} 1.0$ equiv. NaOAc was added. positions on the benzoyl moiety of 1a, no significant steric hindrance was observed (Table 2, 2b-e). Substrates with electronwithdrawing group also gave satisfied yields (Table 2, 2f-k). Interestingly, 2,4-dichloro benzoyl substrate gave the desired product $2 \mathbf{j}$ in $36 \%$ yield accompanied with the 2-dechlorination product $\mathbf{2 g}$ in the same yield (Table 2, 2j). 1-Naphthoyl substrate underwent a smooth reaction to afford the product in $60 \%$ yields (Table 2, 2l). Changing the substituted group on the nitrogen from $n$-butyl to other alkyl groups also gave the corresponding product in moderate yield (Table 2, 2m-o). Substrates with different substituents on the inner side of double bond also gave the desired products in moderate yields, including a spiro product $2 \mathbf{r}$ (Table 2, 2p-r). For substrate with phenyl group on the double bond, no desired product could be found due to the increased steric hindrance, and trifluoromethylated alkene $2 \mathrm{~s}$ was furnished in $66 \%$ yield (Table $2,2 \mathrm{~s}$ ).

Table 2 Scope of substrates ${ }^{a, b}$

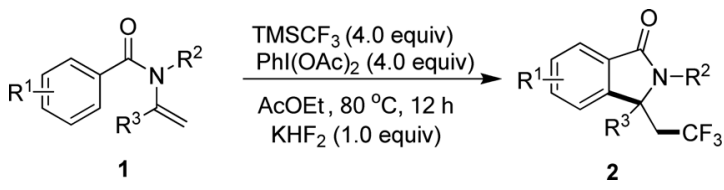

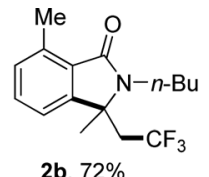

2b, $72 \%$

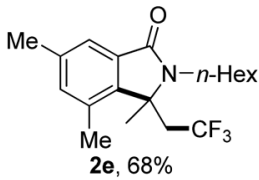<smiles>CCN1C(=O)c2ccc(Br)cc2C1(CC(C)(F)F)C(F)(F)F</smiles>

2h, $71 \%$<smiles>CCCN1C(=O)c2ccc([N+](=O)[O-])cc2C1(C)CC(F)(F)F</smiles>

2k, $67 \%$

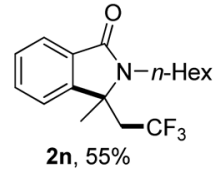<smiles>CCCCN1C(=O)c2ccccc2C1(COC(=O)OCC)CC(F)(F)F</smiles>

2q, $42 \%$<smiles>CCCN1C(=O)c2ccccc2C1(CC(C)C)CC(C)C</smiles><smiles>CCCCN1C(=O)c2ccc(F)cc2C1(C)CC(F)(F)F</smiles><smiles>CCCCN1C(=O)c2c(Cl)cccc2C1(C)CC(F)(F)F</smiles>
$2 i, 70 \%$<smiles>CCCCN1C(=O)c2c(ccc3ccccc23)C1(CC(F)(F)F)CC(F)(F)F</smiles>
21, $60 \%$<smiles>CC(CC1CC1)(CC(F)(F)F)N1C(=O)c2ccccc2C1=O</smiles><smiles>CCCCN1C(=O)c2ccccc2C12CCCCCC2C(F)(F)F</smiles>

2r, $57 \%$ (d.r. $=15: 1)$<smiles>CCCN1C(=O)c2ccc(C)cc2C1(C)CC(F)(F)F</smiles><smiles>CCCN1C(=O)c2ccc(Cl)cc2C1(C)CC(F)(F)F</smiles>

2g, $60 \%$<smiles>CCCCN1C(=O)c2c(Cl)cc(Cl)cc2C1CC(F)(F)F</smiles>

2j, $36 \%+2 \mathrm{~g}, 36 \%$<smiles>CCCN1C(=O)c2ccccc2C1(C)CC(F)(F)F</smiles>

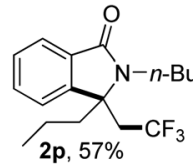<smiles>CCCCN(C(=O)c1ccccc1)C(=CC(F)(F)F)C(F)(F)C(C)(C)C</smiles>

2s. $66 \%$
${ }^{a}$ The reaction was performed with $1(0.2 \mathrm{mmol}), \mathrm{KHF}_{2}(0.2 \mathrm{mmol})$, $\mathrm{TMSCF}_{3}(0.8 \mathrm{mmol}), \mathrm{PhI}(\mathrm{OAc})_{2}(0.8 \mathrm{mmol})$ in EtOAc $(2.0 \mathrm{~mL})$ under $\mathrm{N}_{2}$ at $80{ }^{\circ} \mathrm{C}$ for $12 \mathrm{~h}$ in a sealed tube. ${ }^{b}$ Isolated yields. 
Table 3 Synthesis of the peroxide products ${ }^{a, b}$

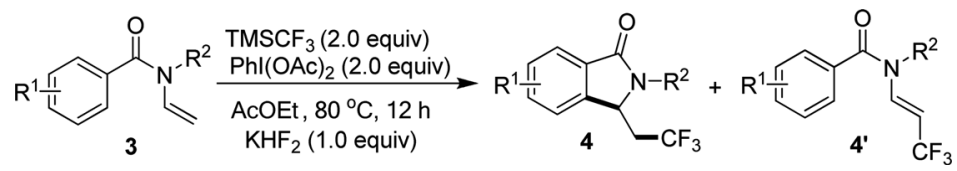

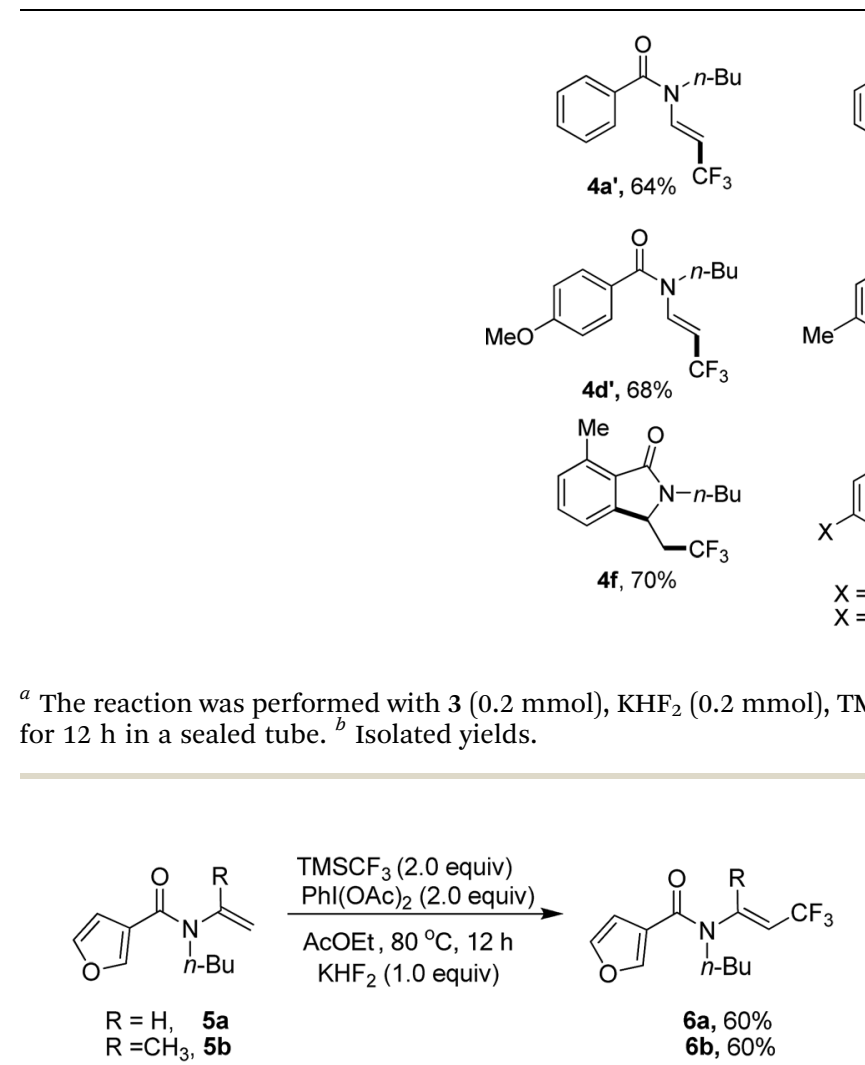

Scheme 2 . Results of heterocyclic substrate $5 a$ and $5 b$.

When $N$ - $n$-butyl- $N$-(2-vinyl) benzamide 3a was subjected to the reaction conditions, no isoindolinone was observed, and the main product was trifluoromethylated alkene (Table $3, \mathbf{4 a}^{\prime}$ ). Changing the $N$-protecting group to $n$-propyl or cyclohexyl also caused the formation of trifluoromethylated alkenes (Table 3, $\mathbf{4} \mathbf{b}^{\prime}-\mathbf{4} \mathbf{c}^{\prime}$ ). It seemed that the substituents on the benzoyl group had significant influence on the reaction result. For example, substrate with methoxy group on the para position of the benzoyl moiety still gave trifluoromethylated alkene as the main product (Table $3, \mathbf{4} \mathbf{d}^{\prime}$ ), but substrate with methyl group on the para position led to a mixture of trifluoromethylated alkene and isoindolinone (Table 3, 4e/4e'). However, substrate with methyl group on the ortho position or halides on the para position of the benzoyl group gave only isoindolinones as the main products (Table 3, $\mathbf{4 f - 4 h}$ ). Substrate with $\mathrm{NO}_{2}$ on the para position displayed low reactivity and no reaction occurred (Table 3, 4i).<smiles>[R10]C(=C)N(C(=O)c1cc[R1](F)cc1)[R1]([H])([H])[H]</smiles>

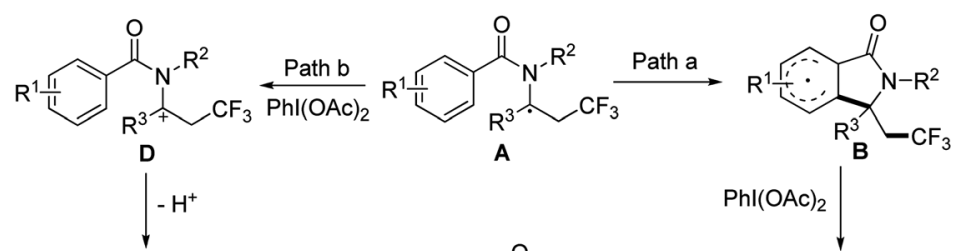<smiles></smiles>

$2 \mathrm{~s}, \mathbf{4}^{\prime}$ or 6<smiles>[R]N1C(=O)c2cc[R1]cc2C1([R])CC(F)(F)F</smiles>

2a-r or 4

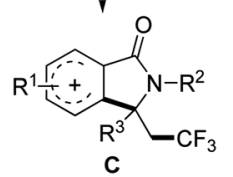

Scheme 3 Possible mechanism. 
Heterocyclic substrate such as $\mathbf{5 a}$ and $\mathbf{5 b}$ was also examined, but no cyclization product could be found and trifluoromethylated alkene $\mathbf{6 a}$ and $\mathbf{6 b}$ was obtained as the only product (Scheme 2).

To gain insights into the reaction mechanism, a control experiment was carried out to elucidate the mechanism. When 1.0 equiv. TEMPO was added to the reaction, the yield of $\mathbf{2 a}$ decreased significantly to $15 \%$, which indicated the possibility of a radical pathway. Based on the control experimental result and the previous investigation on aryltrifluoromethylation of alkenes, plausible mechanism for our methodology is proposed in Scheme 2. In the presence of $\mathrm{KHF}_{2}, \mathrm{TMSCF}_{3}$ reacted with $\mathrm{PhI}(\mathrm{OAc})_{2}$ to generate $\mathrm{CF}_{3}$ radical, then the $\mathrm{CF}_{3}$ radical attacked enamide $\mathbf{1}$ or $\mathbf{3}$ affording radical intermediate $\mathbf{A}$. Depending on the structure of the substrate, intermediate A would be converted to trifluoromethyl-containing isoindolinone or trifluoromethylated alkene according to different pathways as followed: (path a) intramolecular cyclization of $\mathbf{A}$ gave the resulting radical $\mathbf{B}$ with an aryl ring, which was oxidized to intermediate $\mathbf{C}$ then underwent deprotonation to give rise to the final product 2a-r or 4; (path b) A was oxidized to intermediate D then underwent elimination to give trifluoromethylated alkene $2 \mathrm{~s}, \mathbf{4}^{\prime}$ or 6 (Scheme 3 ).

\section{Conclusions}

In conclusion, we have demonstrated a simple, facile approach to trifluoromethyl-containing isoindolinones by radical addition and cyclization of enamides with moderate to good yields under mild conditions. $\mathrm{KHF}_{2}$ was found crucial for this cyclization process and further investigation into the mechanism is currently underway in our laboratory.

\section{Conflicts of interest}

There are no conflicts to declare.

\section{Acknowledgements}

Financial support from Tongji University (20123231) is gratefully acknowledged.

\section{Notes and references}

1 For reviews, see: (a) J. Wang, M. Sanchez-Rosello, J. L. Acena, C. del Pozo, A. E. Sorochinsky, S. Fustero, V. A. Soloshonok and H. Liu, Chem. Rev., 2014, 114, 2432; (b) A. A. Gakh and Y. Shermolovich, Curr. Top. Med. Chem., 2014, 14, 952.

2 (a) Y. Zheng and J. A. Ma, Adv. Synth. Catal., 2010, 352, 2745;

(b) A. Studer, Angew. Chem., Int. Ed., 2012, 51, 8950; (c)

T. Koike and M. Akita, Top. Catal., 2014, 57, 967; (d) M. A. Honey, R. Pasceri, W. Lewis and C. J. Moody, J. Org. Chem., 2012, 77, 1396; (e) J. P. Bouillon, C. Ates, Z. Janousek and H. G. Viehe, Tetrahedron Lett., 1993, 34, 5075.

3 J. Yu, H. Yang and H. Fu, Adv. Synth. Catal., 2014, 356, 3669.
4 (a) J. S. Lin, X. G. Liu, X. L. Zhu, B. Tan and X. Y. Liu, J. Org. Chem., 2014, 79, 7084; (b) J. S. Lin, Y. P. Xiong, C. L. Ma, L. J. Zhao, B. Tan and X. Y. Liu, Chem.-Eur. J., 2014, 20, 1332; (c) H. Y. Zhang, W. Huo, C. Ge, J. Zhao and Y. Zhang, Synlett, 2017, 28, 962.

5 (a) P. Xu, J. Xie, Q. Xue, C. Pan, Y. Cheng and C. Zhu, Chem.Eur. J., 2013, 19, 14039; (b) H. Egami, R. Shimizu and M. Sodeoka, J. Fluorine Chem., 2013, 152, 51; (c) Y. An, Y. Li and J. Wu, Org. Chem. Front., 2016, 3, 570; (d) W. Kong, M. Casimiro, E. Merino and C. Nevado, J. Am. Chem. Soc., 2013, 135, 14480; (e) N. Yang, Z. Li, L. Ye, B. Tan and X. Y. Liu, Chem. Commun., 2016, 52, 9052-9055.

6 (a) L. Li, M. Deng, S. C. Zheng, Y. P. Xiong, B. Tan and X. Y. Liu, Org. Lett., 2014, 16, 504; (b) W. Fu, F. Xu, Y. Fu, C. Xu, S. Li and D. Zou, Eur. J. Org. Chem., 2014, 4, 709; (c) X. Mu, T. Wu, H. Wang, Y. Guo and G. Liu, J. Am. Chem. Soc., 2012, 134, 878; (d) Y. Wang, J. Qiu, D. Kong and F. Chen, Synlett, 2014, 25, 1731.

7 (a) L. Shi, X. Yang, Y. Wang, H. Yang and H. Fua, Adv. Synth. Catal., 2014, 356, 1021; (b) L. Zhang, Z. Li and Z. Q. Liu, Org. Lett., 2014, 16, 3688; (c) W. Wei, J. Wen, D. Yang, X. Liu, M. Guo, R. Dong and H. Wang, J. Org. Chem., 2014, 79, 4225; (d) R. Sakamoto, H. Kashiwagi, S. Selvakumar, S. A. Moteki and K. Maruoka, Org. Biomol. Chem., 2016, 14, 6417; (e) J. Liu, S. Zhuang, Q. Gui, X. Chen, Z. Yang and Z. Tan, Eur. J. Org. Chem., 2014, 15, 3196; (f) Q. Lu, C. Liu, P. Peng, Z. Liu, L. Fu, J. Huang and A. Lei, Asian J. Org. Chem., 2014, 3, 273; (g) F. Yang, P. Klumphu, Y. Liang and B. H. Lipshutz, Chem. Commun., 2014, 50, 936.

8 (a) C. Liu, W. Zhao, Y. Huang, H. Wang and B. Zhang, Tetrahedron, 2015, 71, 4344; (b) X. J. Tang, C. S. Thomoson and W. R. Dolbier, Org. Lett., 2014, 16, 4594-4597; (c) L. Zheng, C. Yang, Z. Xu, F. Gao and W. Xia, J. Org. Chem., 2015, 80, 5730.

9 (a) J. Y. Guo, R. X. Wu, J. K. Jin and S. K. Tian, Org. Lett., 2016, 18, 3850; (b) J. W. Beatty, J. J. Douglas, K. P. Cole and C. R. J. Stephenson, Nat. Commun., 2015, 6, 7919; (c) S. Tang, Z. H. Li, M. W. Wang, Z. P. Li and R. L. Sheng, Org. Biomol. Chem., 2015, 13, 5285.

10 For review and selected examples, see: (a) M. X. Wang, Chem. Commun., 2015, 51, 6039; (b) P. Song, P. Yu, J. S. Lin, Y. Li, N. Y. Yang and X. Y. Liu, Org. Lett., 2017, 19, 1330; (c) Y. Tang, Y. Zhang, K. Wang, X. Li, X. Xu and X. Du, Org. Biomol. Chem., 2015, 13, 7084; (d) X. M. Xu, L. Zhao, J. P. Zhu and M. X. Wang, Angew. Chem., Int. Ed., 2016, 55, 3799; (e) T. Taniguchi, A. Ishita, M. Uchiyama, O. Tamura, O. Muraoka, G. Tanabe and H. Ishibashi, J. Org. Chem., 2005, 70, 1922; (f) L. He, L. Zhao, D. X. Wang and M. X. Wang, Org. Lett., 2014, 16, 5972; $(g)$ G. K. Friestad and Y. Wu, Org. Lett., 2009, 11, 819; (h) C. H. Lei, D. X. Wang, L. Zhao, J. P. Zhu and M. X. Wang, Chem.-Eur. J., 2013, 19, 16981; ( $i$ ) M. N. Zhao, Z. H. Ren, D. S. Yang and Z. H. Guan, Org. Lett., 2018, 20, 1287; (j) C. H. Lei, D. X. Wang, L. Zhao, J. P. Zhu and M. X Wang, J. Am. Chem. Soc., 2013, 135, 4708.

11 (a) R. Ding, Q. Zhang, Y. Xu and T. Loh, Chem. Commun., 2014, 50, 11661; (b) R. Rey-Rodriguez, P. Retailleau, 
P. Bonnet and I. Gillaizeau, Chem.-Eur. J., 2015, 21, 3572; (c) H. Jiang, C. Huang, J. Guo, C. Zeng, Y. Zhang and S. Yu, Chem.-Eur. J., 2012, 18, 15158.

12 For reviews, see: $(a)$ A. Di Mola, L. Palombi and A. Massa, Targets Heterocycl. Syst., 2014, 18, 113; (b) A. Di Mola, L. Palombi and A. Massa, Curr. Org. Chem., 2012, 16, 2302.
13 K. Shen and Q. Wang, Org. Chem. Front., 2016, 3, 222. 14 (a) H. Yu and J. Shen, Org. Lett., 2014, 16, 3204; (b) H. Yu and J. Shen, RSC Adv., 2015, 5, 9815; (c) H. Yu, Y. Xu, R. Dong and Y. Fang, Adv. Synth. Catal., 2017, 359, 39. 